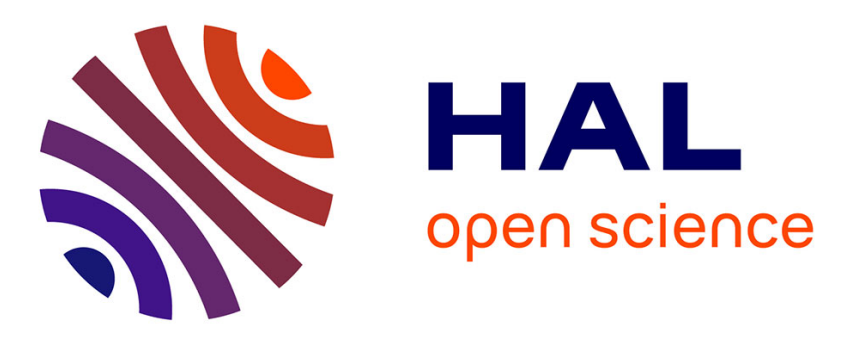

\title{
Hygrothermal study of mortar with date palm fiber reinforcement
}

\author{
Nawal Chennouf, Boudjemaa Agoudjil, Abderrahim Boudenne, Karim \\ Benzarti, Fethi Bouras
}

\section{- To cite this version:}

Nawal Chennouf, Boudjemaa Agoudjil, Abderrahim Boudenne, Karim Benzarti, Fethi Bouras. Hygrothermal study of mortar with date palm fiber reinforcement. THERMOPHYSICS 2018: 23rd International Meeting of Thermophysics 2018, Nov 2018, Smolenice, Slovakia. pp.020013, 10.1063/1.5047607 . hal-03088989

\section{HAL Id: hal-03088989 \\ https://hal.science/hal-03088989}

Submitted on 27 Dec 2020

HAL is a multi-disciplinary open access archive for the deposit and dissemination of scientific research documents, whether they are published or not. The documents may come from teaching and research institutions in France or abroad, or from public or private research centers.
L'archive ouverte pluridisciplinaire HAL, est destinée au dépôt et à la diffusion de documents scientifiques de niveau recherche, publiés ou non, émanant des établissements d'enseignement et de recherche français ou étrangers, des laboratoires publics ou privés. 


\title{
Hygrothermal study of mortar with date palm fiber reinforcement
}

\author{
N. Chennouf ${ }^{1,2,3, \text { a) }}$, B. Agoudji1 ${ }^{2, \text { b) }}$, A. Boudenne ${ }^{1, b)}$, K. Benzarti ${ }^{4}$, F. Bouras ${ }^{3}$ \\ ${ }^{I}$ CERTES, Université Paris Est Créteil Val de Marne, 61 Av. Du Général de Gaulle, \\ 94010 Créteil Cedex, France; \\ ${ }^{2}$ LPEA, Université Batna 1, Les Allées 19 Mai Route de Biskra Batna, Algerie; \\ ${ }^{3}$ University Echahid Hamma Lakhdar El-Oued, PO Box 789 El-Oued, Algerie; \\ ${ }^{4}$ IFSTTAR - Département Matériaux et Structures 14-20 Bd Newton - Cité Descartes \\ 77447 Marne-la-Vallée Cedex 2
}

\author{
a)chennouf-nawel@hotmail.com \\ b)b.agoudjil@yahoo.fr \\ boudenne@u-pec.fr
}

\begin{abstract}
The aim of this study is to characterize the behavior and the effectiveness of a new material both in terms of energy saving and indoor environmental quality. We have focused our investigation on the study of the hygric behavior of Date Palm Fiber "DPF" concrete. The buffer moisture was estimated on the cyclic variation of humidity at isothermal condition, then the effect of temperature and hysteresis on moisture content. The results showed that this new material can be breathable material with excellent moisture buffering capacity and heat regulator thanks to its absorption capacity and low thermal conductivity.
\end{abstract}

\section{INTRODUCTION}

In a context of building energy efficiency and indoor comfort, using hygroscopic materials in building envelopes may moderate the variations of indoor humidity.

New building materials must meet strict requirements on mechanical, thermos-physical and hygric properties. Therefore hygrothermal characterization of new building materials is very important.

Using 15\% of Date Palm Fibers "DPF" loading in the mortar allow obtaining composites that may satisfy both thermal and mechanical properties as structural or insulating materials [1,2].Contrariwise its hygric performance and its ability to moderate the moisture transfer under dynamic condition remains unknown.

This work deals on hygrothermal behavior at material scale using mortar reinforced with Wastes of DPF. Focusing on the ability of DPF materials to moderate cyclic variation of humidity and coupling effect of static conditions of temperature with dynamic conditions of humidity.

\section{MATERIALS}

A single formulation of mortar composites with $15 \mathrm{wt} . \%$ of reinforcement with date palm fibers is used in this study. The samples were prepared in the laboratory by mixing first the fibers (15\%) with cement $(62 \%)$ and sands $(23 \%)$ at dry state in order to obtain a homogeneous mixture, and then the water was gradually added. The mixture was poured into molds of different sizes. After the demolding and drying process we obtained several samples presented in Figure 1. 


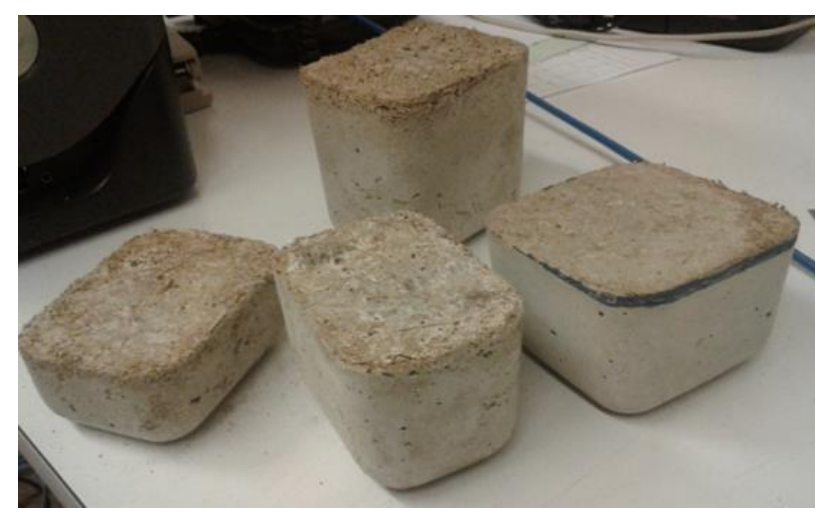

Figure 1: samples testing

\section{METHODS}

\section{Moisture buffer value}

One way to quantify the regulation capacity of the indoor air humidity is to evaluate the moisture buffer capacity $\mathrm{MBV}$, i.e. the moisture exchange capacity under a dynamic exposure to ambient relative humidity (RH) cycle.

For the MBV measurement, we used the Nordtest project process [3], where the parallelepiped samples were sealed on the five sides with aluminum in order to insure 1D transfer. The open sample surface of $95 \mathrm{~mm} \times 65 \mathrm{~mm}$ of side and $60 \mathrm{~mm}$ of thickness is thicker than the moisture depth penetration [4]. Afterward, the samples were placed in climatic chamber (HPP 750 Memmert) at $23^{\circ} \mathrm{C}$ and $50 \% \mathrm{RH}$ until that two successive daily weighed agree to within $0.1 \%$ of their mass variation. After the stabilization step, the samples were exposed at room temperature $\left(23^{\circ} \mathrm{C}\right)$ and to the variation of $\mathrm{RH}$ during 8 hours at $75 \% \mathrm{RH}$ and 16 hours at $33 \% \mathrm{RH}$. The same protocol was also repeated at temperature of $10^{\circ} \mathrm{C}$.

The MBV value is calculated at a steady state according to the following Equation 1:

$$
M B V=\frac{\Delta m}{A\left(R H_{\text {high }}-R H_{\text {low }}\right)}
$$

With MBV: moisture buffer value $\left(\mathrm{kg} /\left(\mathrm{m}^{2} \% \mathrm{RH}\right)\right), \Delta \mathrm{m}$ : moisture uptake/release during the period (kg), A: open surface area $\left(\mathrm{m}^{2}\right), \mathrm{RH}_{\text {high/low }}$ : high/low relative humidity level .

\section{Theory}

The only use of the sorption curve that considered as physical limits to changes in moisture content of materials cannot provide good prediction of the hysteretic behavior and the water content for a usual use.

In order to analyze the water content under a dynamic relative humidity conditions, before performing the steps previously presented for the MBV measurement, the samples were dried for $120 \mathrm{~h}$ in an oven at $62{ }^{\circ} \mathrm{C}$ in order to extract all moisture or water. The water content was calculated from the following Equation:

$$
w=\frac{m_{w}-m_{0}}{m_{0}}
$$

With w: water content of the sample $(\%), \mathrm{m}_{\mathrm{w}}$ : weight of the wet specimen $(\mathrm{g}), \mathrm{m}_{0}$ : weight of the dry specimen (g)

The experimental step was followed by the determination of the ideal MBV. This buffer property represents a dynamic characteristic defined also by Nordest project [3], is calculated using the moisture effusivity $b_{m}$ which is determined under steady state and equilibrium conditions using the results obtained by Haba et al. [5] Equation 3 and 4:

$$
M B V=0.0568 p_{s} b_{m} \sqrt{t_{p}}
$$

$b_{m}$ in a similar way to the definition of thermal effusivity, we can describe the ability of a material to absorb or release moisture $\left[\mathrm{kg} /\left(\mathrm{m}^{2} \mathrm{~Pa} \cdot \mathrm{s}^{1 / 2}\right)\right]$. 
$p_{s}$ :is saturation vapor pressure $[\mathrm{Pa}]$.

$$
b_{m}=\sqrt{\frac{\delta p \frac{\partial w}{\partial R H}}{P_{S}}}
$$

The penetration depth " $d_{p}$ " represents the depth where the amplitude of moisture content variation exceed $1 \%$ of the surface amplitude (calculated using Equation 5).

$$
d_{P}=4.61 \sqrt{\frac{D_{w} t_{p}}{\pi}}
$$

Where $D_{w}$ is the moisture diffusivity of the material obtained in [5], $t_{p}$ (24hours) time period.

\section{RESULTS}

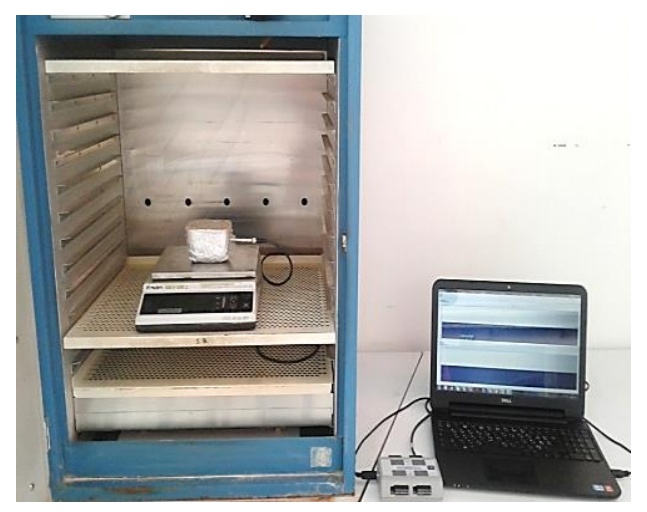

Figure 2: Experimental device used to evaluate moisture buffering of $P D C$.

To characterize the ability of the PDC to buffering (store and release) the moisture of the surrounding air; the method defined by the Nordest project [3] was used. This protocol consists to expose the sample to constant temperature with a cyclic variation of RH between high (75\%) and low (33\%) values for 8 and 16 hours respectively. In this paper, we have used a protocol for two different temperatures $\left(23^{\circ} \mathrm{C}\right.$ and $\left.10^{\circ} \mathrm{C}\right)$ in order to study the effect of temperature on the PDC moisture buffer.

The moisture buffer value obtained by the experimental measurement is represented in table 1.

According to the classification of the moisture buffer performance proposed by NORDTEST protocol [3] this material is classified as "excellent" $(2<\mathrm{MBV})$.

The DPF concrete is classed as an excellent regulator of indoor humidity, It can be seen that the highest MBV value was achieved for the DPF concrete composite $\left[2.97 \mathrm{~g} /\left(\mathrm{m}^{2} . \% \mathrm{RH}\right)\right]$ followed by the other bio-sourced materials documented in the literature, whereas traditional building materials such as concrete and brick showed the lowest MBV values.

Exploring results in terms of adsorption isotherm, the high moisture adsorption capacity of DPF concrete is $2.1 \times$ $10^{-9} \mathrm{~m}^{2} \mathrm{~s}^{-1}[3]$ and this is also reflected in their corresponding MBV values. 
Table 1: Comparison of the moisture buffer value of DPC mortar with several building materials from the literature.

\begin{tabular}{cc} 
Materials & $\begin{array}{c}\text { MBV } \\
{[\mathrm{g} /(\mathrm{m} 2 \% \mathrm{RH})]}\end{array}$ \\
\hline $\begin{array}{c}\text { Brick } \\
\text { Concrete }\end{array}$ & 0.39 \\
$\begin{array}{c}\text { Laminated Wood } \\
\text { with Varnish }\end{array}$ & 0.42 \\
Cellular concrete & 0.46 \\
$\begin{array}{c}\text { Prefabricated } \\
\text { Hemp Concrete }\end{array}$ & 0.96 \\
$\begin{array}{c}\text { Molded Hemp } \\
\text { Concrete } \\
\text { DPF concrete }\end{array}$ & 2.94 \\
\hline
\end{tabular}

Thanks to this characteristic, the studied material can be considered as good candidate to moderate indoor air relative humidity amplitudes, and therefore allow improving occupant's hygrothermal comfort sensation.

Table 2 reports the calculated value of $\mathrm{MBV}_{\text {ideal }}$ (Cf. Equations 3, 4 and 5 ) and the moisture penetration depth for the DPF concrete material deduced from experimental results of Haba et al. [5], and the same quantities obtained from literature data for some other bio-based materials.

Table 2: $\mathrm{MBV}_{\text {ideal }}, \mathrm{dP}_{\mathrm{P} .1 \%}, \mathrm{~b}_{\mathrm{m}}, \mathrm{D}_{\mathrm{w}}$ of DPF concrete.

\begin{tabular}{ccccc} 
& $\begin{array}{c}\mathrm{D}_{\mathrm{w}} \\
{\left[\mathrm{m}^{2} / \mathrm{s}\right]}\end{array}$ & $\begin{array}{c}\mathrm{b}_{\mathrm{m}} \\
{\left[\mathrm{kg} / \mathrm{m}^{2} . \mathrm{Pa} \mathrm{s}^{1 / 2}\right]}\end{array}$ & $\begin{array}{c}\text { MBV } \\
{\left[\mathrm{g} / \mathrm{m}^{2} . \% \mathrm{RH}\right]}\end{array}$ & $\begin{array}{c}\mathrm{dP} .1 \% \\
{[\mathrm{~cm}]}\end{array}$ \\
\hline $\begin{array}{c}\mathrm{DPF} \\
\text { concrete }\end{array}$ & $2.10 \times 10^{-9}$ & $8.07 \times 10^{-7}$ & 3.79 & 3.50 \\
\hline
\end{tabular}

These values represent a referential values, it has been calculated assuming sinusoidal variation, while the Nordtest protocol uses exposures change. It can be only considered as an approximation.

Fig. 3 shows the rates of adsorption and desorption of DPF concrete during the MBV cycles. In particular, we observe hysteresis in the sorption curves. Which is a common feature for biobased materials, although significant differences can be observed among this type of materials and also depend on the temperature as it is shown for DPF concrete at $23{ }^{\circ} \mathrm{C}$ is more important then at $10^{\circ} \mathrm{C}$.

Water content determined at the two considered temperatures, i.e. 23 and $10^{\circ} \mathrm{C}$. It is noted that this property decreases with the decrease of the temperature and thus allow mitigating the transport phenomena. This can be explained by the increase of water viscosity which decreases the liquid permeation at high humidity [6]. 


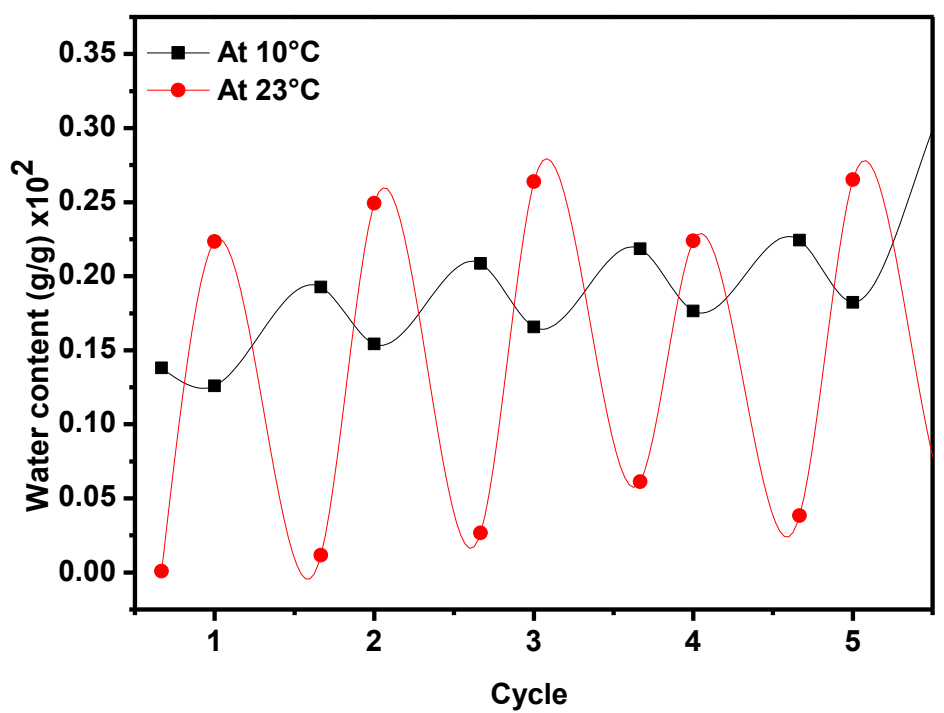

Figure 3: Moisture content uptake and release at $\mathrm{T}=23^{\circ} \mathrm{C}$ and $\mathrm{T}=10^{\circ} \mathrm{C}$ for 5 cycles of $\mathrm{MBV}$ measurement.

\section{CONCLUSION}

In the present work, we have investigated experimentally the hygrothermal behavior of DPF concrete at the material scale. We have notice that these new bio based materiel exhibit an excellent moisture buffer value.

This paper provides also some information concerning the effects of temperature. These effects were assessed experimentally on the moisture buffer value at $10^{\circ} \mathrm{C}$ and $23^{\circ} \mathrm{C}$. The results showed that a decrease of temperature results a decrease of moisture content of DPF concrete.

It can be concluded that the use of this DPF concrete can be advantageous in terms of moisture control and for minimizing interstitial condensation when exposed to high RH environments.

\section{ACKNOWLEDGMENTS}

This research was conducted with financial support of PHC TASSILI Project 16MDU976. 


\section{REFERENCES}

[1] N. Benmansour, B. Agoudjil A. Gherabli, A. Kareche, A. Boudenne, "Thermal and mechanical performance of natural mortar reinforced with date palm fibers for use as insulating material in building," Energy and Building, vol. 81, pp. 98-104, 2014.

[2] B. Agoudjil, A. Boudenne, L. Ibos, "Renewable materials to reduce building heat loss: Characterization of date palm wood," Energy and Buildings, vol. 43, pp. 491-497, 2011.

[3] C. Rode, "Moisture Buffering of Building Materials," Report BYG.DTU R-126, ISSN 16012917 ISBN 87-787-195, 2005.

[4] C. Rode, A. K. GRAU, "Moisture Buffering of Building Materials," Building Physics, vol. 31, pp. 333-360, 2008.

[5] B. Haba, B. Agoudjil A. Boudenne, K. Benzarti, "Hygric properties and thermal conductivity of a new insulation material for building based on date palm concrete," Construction and Building Materials,, vol. 154, pp. 963-971, 2017.

[6] B. Mazhoud, F. Collet, S.Pretot, J.Chamoin, "Hygric and Thermal Properties of Hemp-Lime Plasters", vol 96, pp 206-216, 2016 